\title{
Supplemental - Evidence for microbial mediated nitrate cycling within floodplain sediments during groundwater fluctuations
}

Nicholas J Bouskill ${ }^{1}$, Mark E Conrad ${ }^{1}$, Markus Bill ${ }^{1}$, Eoin L Brodie ${ }^{1}$, Yiwei Cheng ${ }^{1}$, Chad Hobson ${ }^{1}$, Matthew Forbes ${ }^{2}$, Karen L Casiotti ${ }^{2}$, and Kenneth H Williams ${ }^{1}$

${ }^{1}$ Earth and Environmental Sciences Area, Lawrence Berkeley National Laboratory, Berkeley, CA, 94720

${ }^{2}$ Department of Environmental Earth System Science, Stanford University, Stanford, CA, 94305

Correspondence to: Nicholas Bouskill (njbouskill@lbl.gov)

\section{Supplemental Methods}

\subsection{Fraction of nitrate formed by nitrification}

A simple isotope mixing model (Wexler et al., 2014) was used to estimate the contribution of different sources (i.e., $\mathrm{NO}_{3}{ }^{-}$ deposition and infiltration or nitrification) to $\mathrm{NO}_{3}{ }^{-}$accumulating in the unsaturated zone prior to groundwater rise. Using

5 literature values for two different end members (nitrification and snowmelt) we estimated the source of well $\mathrm{NO}_{3}{ }^{-}$prior to the onset of denitrification (toward the beginning of May) as follows,

Well $\delta^{18} \mathrm{O}_{\mathrm{NO}_{3}}=f *$ Snow $\delta^{18} \mathrm{O}_{\mathrm{NO}_{3}}+(1-f)$ Nitrif $\delta^{18} \mathrm{O}_{\mathrm{NO}_{3}}$

which can be rearranged to give $f$,

$f=\frac{\left(\text { Well } \delta^{18} \mathrm{O}_{\mathrm{NO}_{3}}-\text { Nitrif } \delta^{18} \mathrm{O}_{\mathrm{NO}_{3}}\right)}{\left(\text { Snow } \delta^{18} \mathrm{O}_{\mathrm{NO}_{3}}-\text { Nitrif } \delta^{18} \mathrm{O}_{\mathrm{NO}_{3}}\right)}$

Values for $\delta^{18} \mathrm{O}_{\mathrm{NO}_{3}}$ from snowmelt were taken from previously published values (Campbell et al., 2002; Kendall et al., 2007), estimated to be $\sim+67 \%$ (with a range of +40 to $+70 \%$ ). Two approaches were taken to estimate the $\delta^{18} \mathrm{O}_{\mathrm{NO}_{3}}$ imparted by nitrification (Fang et al., 2012). The first approach follows the assumption that nitrification occurs with no exchange between nitrification intermediates and water, though isotopic fractionation during oxygen atom incorporation is accounted for (Buchwald et al., 2012):

$15 \delta^{18} O_{\mathrm{NO}_{3}}=\frac{2}{3} \delta^{18} \mathrm{O}_{\mathrm{H}_{2} \mathrm{O}}+\frac{1}{3} \delta^{18} \mathrm{O}_{\mathrm{O}_{2}}-\frac{1}{3}\left({ }^{18} \varepsilon_{K, \mathrm{O}_{2}}+{ }^{18} \varepsilon_{K, \mathrm{H}_{2} \mathrm{O}, 1}+{ }^{18} \varepsilon_{K, H_{2} O, 2}\right)$

Here we used a fixed value of $23.5 \%$ for the $\delta^{18} \mathrm{O}_{\mathrm{O}_{2}}$, and measurements from the Rifle groundwater where $\delta^{18} \mathrm{O}_{H_{2} O}$ spans a range of -13.3 to $-14.7 \%$ o between the 2 and $3 \mathrm{~m}$ depths considered in this study (Ken Williams, pers. comm). ${ }^{18} \varepsilon_{K, O_{2}}$ and 
${ }^{18} \varepsilon_{K, H_{2} O, 1}$ represents the isotopic fractionation associated with ${ }^{18} \mathrm{O}$ incorporation from $\mathrm{O}_{2}$, and $\mathrm{H}_{2} \mathrm{O}$ during the first step of nitrification, ammonia oxidation. Similarly, ${ }^{18} \varepsilon_{K, H_{2} O, 2}$ represent the isotopic fractionation associated with ${ }^{18} \mathrm{O}$ incorporation into $\mathrm{NO}_{3}$ from $\mathrm{H}_{2} \mathrm{O}$ during nitrite oxidation. Values for ${ }^{18} \varepsilon_{K, O_{2}},{ }^{18} \varepsilon_{K, H_{2} O, 1}$, and ${ }^{18} \varepsilon_{K, H_{2} O, 2}$ were derived from a previously published range of values (Buchwald and Casciotti, 2010; Casciotti et al., 2010), where ${ }^{18} \varepsilon_{K, O_{2}}+{ }^{18} \varepsilon_{K, H_{2} O, 1}$ was estimated as

$5-37.6$ to $-17.9 \%$ (Casciotti et al., 2010), while ${ }^{18} \varepsilon_{K, H_{2} O, 2}$ has been estimated to be -18.2 to $-12.8 \%$ o (Buchwald and Casciotti, 2010). The range of nitrification $\delta^{18} \mathrm{O}_{\mathrm{NO}_{3}}$ values obtained through this first approach is -20.3 to -11.2. \%o.

The second approach allows full exchange of oxygen atoms between $\mathrm{NO}_{2}{ }^{-}$and $\mathrm{H}_{2} \mathrm{O}$ during nitrification (Buchwald and Casciotti, 2010; Casciotti et al., 2010; Buchwald et al., 2012):

$\delta^{18} \mathrm{O}_{\mathrm{NO}_{3}}=\delta^{18} \mathrm{O}_{\mathrm{H}_{2} \mathrm{O}}+\frac{2}{3}\left({ }^{18} \varepsilon_{e q}\right)-\frac{1}{3}\left({ }^{18} \varepsilon_{K, \mathrm{H}_{2} \mathrm{O}, 2}\right)$

where ${ }^{18} \varepsilon_{e q}$ is the equilibrium isotope effect between $\mathrm{NO}_{2}{ }^{-}$and $\mathrm{H}_{2} \mathrm{O}$, which is approximately $14-15 \%$ at room temperature (Casciotti et al., 2007; Buchwald and Casciotti, 2013). The range of nitrification $\delta^{18} \mathrm{O}_{\mathrm{NO}_{3}}$ values obtained through this second approach is -11.5 to $-7.7 \%$.

\subsection{Model Description}

To further understand the factors controlling rates of nitrogen cycling and nitrogen loss from the Rifle aquifer, we represent an ecosystem of interacting functional microbial guilds competing for carbon and nitrogen in a manner theoretically analogous to the $\mathrm{R}^{*}$ concept (Tilman, 1977; 1987). The different microbial guilds represent facultative heterotrophs (denitifiers), and obligate and mixotrophic autotrophs (aerobic and anaerobic ammonia-oxidizing organisms and nitrite-oxidizing bacteria, Figure S1). The model framework is based on a previously published trait-based model of nitrification (Bouskill et al., 2012; Le Roux et al., 2016), with several modifications: (1) the present model develops this earlier structure through the representation of functional guilds (defined here as discrete collection of organisms performing a common metabolism) as ecological strategies that encompass a variance in trait space rather than representing specific phylogenetic groups. This reduces the complexity of certain functional guilds from previous representations. For example, the ammonia-oxidizing organisms have been reduced to four functional guilds from the 8 established previously (Bouskill et al., 2012). (2) Improved representation of the nitrite oxidizing bacteria encompassing both obligate autotrophic and mixotrophic metabolisms. The rationale for which has been described previously (Le Roux et al., 2016). (3) Inclusion of thermodynamically driven heterotrophic reactions based on previously published work (LaRowe and Van Cappellen, 2011; LaRowe et al., 2012), where the electron donor and acceptor pairing determines energy production (i.e., ATP equivalents) and growth rates (see below). (4) Representation of the anaerobic ammonia oxidizing (anammox) planctomycetes, with trait ranges derived from recently published ecophysiological data (Kartal et al., 2011).

30 Heterotrophic functional guilds: The heterotrophs are represented by four distinct guilds that include three facultative aerobes with the metabolic flexibility to switch from respiration via oxygen $\left(\mathrm{O}_{2}\right)$ as an electron acceptor, to nitrate $\left(\mathrm{NO}_{3}{ }^{-}\right)$. Two of these guilds catalyze complete denitrification pathways (i.e., from $\mathrm{NO}_{3}{ }^{-}$to $\mathrm{N}_{2}$ ), but differ in their affinity $\left(\mathrm{K}_{M}\right)$ for 
$\mathrm{O}_{2}$ and $\mathrm{NO}_{3}{ }^{-}$, while the third guild mediates only partial denitrification to $\mathrm{N}_{2} \mathrm{O}$ rather than $\mathrm{N}_{2}$. The final guild is an obligate anaerobe and $\mathrm{N}_{2} \mathrm{O}$ consumer (Jones et al., 2014; Sanford et al., 2012) reducing $\mathrm{N}_{2} \mathrm{O}$ to $\mathrm{N}_{2}$.

Within each guild there are three ecotypes that couple different electron acceptors (either $\mathrm{O}_{2}$ or $\mathrm{NO}_{3}{ }^{-}$) to one of three different electron donors (ED 1, 2, 3). These electron donors differ in their $\mathrm{C}: \mathrm{N}$ ratios, on the basis of measurements made

5 at the Rifle site $(\mathrm{C}: \mathrm{N}=5,11,15$,$) , and their thermodynamic activity coefficients \left(\mathrm{k}_{e q}\right.$, table $\left.\mathrm{S} 2\right)$. The three ecotypes are parameterized as diverse ecological strategies, and differ in their capabilities to utilize the $\mathrm{ED}_{1-3}$. Ecotype 1 specializes on one compound only $\left(\mathrm{ED}_{1}, \mathrm{C}: \mathrm{N}=5\right.$ ), with no capacity to take up $\mathrm{ED}_{2}$ or $\mathrm{ED}_{3}$. By contrast ecotype 3 can utilize all three different electron donors, and ecotype 2 showing an intermediate strategy, utilizing $\mathrm{ED}_{1}$ and $\mathrm{ED}_{2}(\mathrm{C}: \mathrm{N}=11)$. Physiological trade-offs constrain the metabolically diverse ecotypes to specific regions of the trait-space because the capacity to take-up and utilize multiple donor sources trades-off against growth rate. Consequentially, specialists have a higher maximal growth rate relative to the other two ecotypes, while the generalist has a lower growth rate. The heterotrophic functional guilds also conform to the general trade-off rules specified below. The rate of nitrogen loss and nitrous oxide $\left(\mathrm{N}_{2} \mathrm{O}\right)$ production is dependent on multiple interacting factors, including, microbial community structure, nitrification rate, nutrient concentrations, organic matter stoichiometry, redox conditions and temperature (Groffman, 2012; Wallenstein et al., 2006). Trait values are given in Table $\mathrm{S} 1$, and are derived from previously published literature values in an attempt to span trait variance and represent different ecological strategies.

\subsubsection{Carbon and nutrient cycling}

The three ED pools have different chemical structures (represented with different thermodynamic equilibrium constants, see table S2) and different C:N stoichiometries (5 - 15). Heterotrophic mineralization of substrate pools yields ammonia $\left(\mathrm{NH}_{3}{ }^{+}\right)$ that, under aerobic conditions, can be nitrified to $\mathrm{NO}_{2}{ }^{-}$and then to $\mathrm{NO}_{3}{ }^{-}$via ammonia- and nitrite-oxidizing organisms. Under aerobic unsaturated conditions in the aquifer, $\mathrm{NO}_{3}{ }^{-}$builds up. The substrate and nutrient dynamics are represented as follows,

$$
\begin{aligned}
& \frac{d E D}{d t}=\sum_{j} m \cdot B_{i, j}-\sum_{j} U\left(E D, B_{i, j}, T\right) \\
& \frac{d N}{d t}=\sum_{j} m \cdot B_{i, j}-\sum_{j} U\left(N, B_{i, j} T\right)
\end{aligned}
$$

where, ED and $\mathrm{N}$ represent the concentration (in $\mathrm{M}$ ) of the electron donors and nutrients, respectively. $\mathrm{U}$ represents uptake by different functional guilds (kinetics outlined below), and $\mathrm{T}$ is the temperature $(\mathrm{C})$. The initial inputs are the concentration of electron donor $\left(\mathrm{ED}_{1,2,3}\right)$, and oxygen concentrations. These values are prescribed in the model on the basis of measured organic matter fractions and oxygen concentrations within the Rifle aquifer. 


\subsubsection{Microbial physiology and nutrient uptake}

Below we describe the equations determining resource uptake and utilization for heterotrophic organisms and anaerobic ammonium oxidation. The relevant equations for the AOO and NOB uptake and growth have been described previously (Bouskill et al., 2012; Le Roux et al., 2016). Microbial biomass dynamics are governed by substrate and nutrient uptake, resulting in

5 biomass development, and balanced by a first order mortality rate, according the following,

$\frac{d_{B}}{d T}=d_{B}-m \cdot B_{T}^{i}$

where, $d_{B}$ represents biomass development through cell division (equation 9), and $m$ represents a biomass dependent $\left(B_{T}\right)$ mortality rate. The exception to this relationship occurs during detoxification of $\mathrm{NO}_{2}$ by ammonia-oxidizers, which uses biomass as the energy source to oxidize $\mathrm{NO}_{2}$ via a series of intermediates ( $\mathrm{NO}$ and $\mathrm{N}_{2} \mathrm{O}$ )(Bouskill et al., 2012). The detoxification term modifies the biomass dynamics as follows,

$\frac{d B}{d T}=D_{B}-m \cdot B_{T}^{i}-\frac{1}{4}\left(l_{D E T O X}^{N O_{2}}+l_{D E T O X}^{N O}\right)$

where, $l_{\text {DETOX }}\left(\mathrm{Ms}^{-1}\right)$ represents the loss of biomass due to the detoxification of either $\mathrm{NO}_{2}$ or NO. The $\frac{1}{4}$ represents the stoichiometric relationship between $\mathrm{AOB}$ biomass loss and $\mathrm{NO}_{2}$. $\mathrm{NO}$ is detoxified to $\mathrm{N}_{2} \mathrm{O}$ and is the dominant pathway via which nitrifiers contribute to the $\mathrm{N}_{2} \mathrm{O}$ production. The decomposition of hydroxylamine $\left(\mathrm{NH}_{2} \mathrm{OH}\right)$ is a second pathway

15 through which ammonia-oxidiers produce $\mathrm{N}_{2} \mathrm{O}$, however, this is likely of secondary important to total $\mathrm{N}_{2} \mathrm{O}$ flux (Bouskill et al., 2012). The rate of microbial cell division $\left(D_{B}\right)$ can then be given by,

$d_{B}=\mu_{M A X}^{B} \cdot \min \left(d_{i}\right) \cdot B_{T}$

where, $\mu_{M A X}^{B}$ represents the maximum growth rate $\left(s^{-1}\right)$ of the members of the different function guilds, and $B_{T}$ represents the total microbial biomass, which is dependent on the rate of resource utilization.

\subsection{Resource utilization}

Here, the uptake of different substrates and electron acceptors is represented using Michaelis Menton (MM) kinetics, which have been conventionally employed to represent resource uptake by bacteria (Litchman et al., 2015).

Anaerobic ammonia oxidizers: The uptake of $\mathrm{NH}_{4}$ and $\mathrm{NO}_{2}$ by anammox bacteria follows a dual MM expression with inhibition by $\mathrm{O}_{2}$ :

$25 V^{N H_{4}}=V_{M A X}^{N H_{4}} \cdot \frac{\left[N H_{4}\right]}{K_{N H_{4}}^{M}+\left[N H_{4}\right]} \cdot \frac{\left[O_{2}\right]}{K_{O_{2}}^{i}+\left[O_{2}\right]}$ 
where $\mathrm{V}_{M A X}^{N H_{4}}$ represents the maximum uptake rate for $\mathrm{NH}_{4}, \mathrm{~K}_{M}^{N H_{4}}$ represents the affinity constant for $\mathrm{NH}_{4}$ and $\mathrm{K}_{i}^{\mathrm{O}_{2}}$ represents the inhibition constant for $\mathrm{O}_{2}$.

From this, the uptake of $\mathrm{NO}_{2}$ is calculated according to the stoichiometric ratio of the anammox reaction,

$1 \mathrm{NH}_{4}+1.3 \mathrm{NO}_{2} \longrightarrow 1 \mathrm{~N}_{2}+0.3 \mathrm{NO}_{3}+2 \mathrm{H}_{2} \mathrm{O}$

5 The anammox bacteria maintain a stoichiometric $\mathrm{C}: \mathrm{N}$ ratio $(=6.6)$ through the uptake and assimilation of $\left.\mathrm{N}_{(a s} \mathrm{NH}_{4}\right)$ into biomass, according to,

$V^{N}=V_{M A X}^{N} \cdot \frac{[N]}{K_{M}^{N}+[N]}$

Finally, anammox increase biomass (eq. 8) via carbon fixation using energy generated through ammonia oxidation. $\mathrm{CO}_{2}$ uptake proceeds according to,

$10 V^{C O_{2}}=V_{M A X}^{N} \cdot \frac{\left[\mathrm{CO}_{2}\right]}{K_{M}^{C O_{2}}+\left[\mathrm{CO}_{2}\right]}$

Facultative heterotrophs: Heterotrophic respiration rates are calculated according to the following,

$r_{R}=V_{M A X} \cdot\left[B_{j, t}\right] \cdot f(E D) \cdot f(E A) \cdot f(T)$

where, $\mathrm{V}_{\text {MAX }}$ is the maximum uptake rate for either the ED or EA, $\mathrm{f}(\mathrm{ED})$ and $\mathrm{f}(\mathrm{EA})$ are MM functions for each ED and EA (i.e., $\mathrm{O}_{2}, \mathrm{NO}_{3}$ ), and $\mathrm{f}(\mathrm{T})$ represents the thermodynamic potential, which is a dimensionless thermodynamic potential factor. The

$15 \mathrm{f}(\mathrm{T})$ function constrains the microbial respiration rate based on differences between the available energy from the environment (i.e., coupled ED and EA) and a minimum amount of energy harvested by microbial cells for growth and maintenance $\left(\Delta \mathrm{G}_{\min }\right)$. The formulation of $\mathrm{f}(\mathrm{T})$ in recent years, illustrated the increasing recognition of the need of a more robust method to model microbial respiration rates, which are typically constrained by low energy availability ${ }^{9,17}$. At present, two formulations of $\mathrm{f}(\mathrm{T})$ that differ in the proxy used to represent $\Delta \mathrm{G}_{\min }$ are commonly used (Jin and Bethke, 2007; LaRowe et al., 2012). For example,

20 Jin and Bethke (Jin and Bethke, 2007) represent $\Delta \mathrm{G}_{\min }$ by the energetics of ATP synthesis by microorganisms, while LaRowe and coworkers (LaRowe et al., 2012) proposed $\Delta \mathrm{G}_{\min }$ be represented by the energetics of microbial membrane potential. In the current model, the $\mathrm{f}(\mathrm{T})$ formulation of LaRowe et al (LaRowe et al., 2012) has been implemented,

$f(T)=\frac{1}{e^{\left(\frac{\Delta G_{r}+F \Delta \psi}{R T}\right)}+1}$ 
where, $\Delta \psi$ is the membrane potential, which is set here at a value optimal for ATP production (120 mV, (LaRowe et al., 2012), $\mathrm{R}$ is the gas constant ( $\left.8.314 \mathrm{~J} \mathrm{~mol}^{-1} \mathrm{~K}^{-1}\right)$, $\mathrm{T}$ is temperature in Kelvin, and $\mathrm{F}$ is Faraday's constant $\left(96485.34 \mathrm{C} \mathrm{mol}^{-1}\right)$. $\Delta \mathrm{G}_{r}$ is the Gibbs free energy of the redox reaction per electron transferred, and is calculated as:

$\Delta G_{r}=-R T \ln \left(\frac{K}{Q}\right)$

where $\mathrm{K}$ is the reaction equilibrium constant while $\mathrm{Q}$ is the reaction quotient of the same reaction. $\mathrm{Q}$ is derived as,

$Q=\prod_{i} a_{i}^{v_{i}}$

where, $a_{i}$ and $v_{i}$ are the activity coefficient $\left(\mathrm{mol}^{-1}\right)$ and the stoichiometric coefficient of chemical species (i) in the redox reaction.

Temperature response: We assume that the microorganisms within the aquifer are adapted to the average annual temperature within the TT- 03 well (mean \pm std $\operatorname{dev}=13.5 \pm 0.8^{\circ} \mathrm{C}$ ). The temperature response is then represented using a previously published function that fixes the shape of the specific activity of a transporter or enzyme as a gaussian distribution across a gradient of temperature (Rosso et al., 1995).

\subsubsection{Trade-offs}

Metabolic trade offs are key in determining the relative fitness of individual cells across gradients and the evolution of the microbial community (Beardmore et al., 2012; Edwards et al., 2013). In the present model we represent several hardwired trade-offs that may constrain metabolism.

Affinity uptake trade-off: A negative relationship has been observed between the maximal rate of substrate uptake $\left(\mathrm{V}_{M A X}\right)$ and the uptake affinity $\left(\mathrm{V}_{M A X} / K_{M}\right)$ (Button et al., 2004). While the precise shape of this trade-off is currently unclear, in the present model we represent a tentative linear relationship between these two traits. This relationship is predominantly used for distinguishing different heterotrophic organisms (from oligo- to copiotrophic bacteria), where the organisms are differentiated on the basis of substrate affinity and uptake. These traits are generally standardized across the other guilds.

Growth-rate physiological efficiency trade-off: Microbial CUE is a non-linear and hysteretic trait (Tang and Riley, 2014), that varies as a function of temperature and mineral interactions. However, to reduce the complexity associated with this trait, we parameterize it as a static value related to the growth rate of different microbial guilds and modified by temperature. In the present model we represent fast growing heterotrophic organisms as metabolically inefficient, with a lower CUE and associated greater production of $\mathrm{CO}_{2}$ / unit $\mathrm{C}$ taken up (Molenaar et al., 2009). Slow growing organisms, however, partition more carbon (either fixed or taken up from the soil) to the biomass rather than to maintenance.

Code availability: Scripts used in the current simulations are available online (www.njbouskill.wordpress.com/codes). 


\section{References}

Beardmore, R. E., Gudelj, I., Lipson, D. A. and Hurst, L. D.: Metabolic trade-offs and the maintenance of the fittest and the flattest. Nature, 472(7343), 342-346, doi:10.1038/nature09905, 2012.

Bouskill, N. J., Tang, J., Riley, W. J. and Brodie, E. L.: Trait-based representation of biological nitrification: model development, testing, and predicted community composition. Front. Microbiol., 3, 364, doi:10.3389/fmicb.2012.00364, 2012.

Buchwald, C. and Casciotti, K. L.: Oxygen isotopic fractionation and exchange during bacterial nitrite oxidation. Limnol. Oceangr., 55(3), 1064-1074, doi:10.4319/lo.2010.55.3.1064, 2010.

Button, D. K., Robertson, B., Gustafson, E. and Zhao, X.: Experimental and Theoretical Bases of Specific Affinity, a Cytoarchitecture-Based Formulation of Nutrient Collection Proposed To Supercede the Michaelis-Menten Paradigm of Microbial Kinetics. Applied and Environmental Microbiology, 70(9), 5511-5521, doi:10.1128/AEM.70.9.5511-5521.2004, 2004.

Casciotti, K. L., McIlvin, M. and Buchwald, C.: Oxygen isotopic exchange and fractionation during bacterial ammonia oxidation. Limnol. Oceangr., 55(2), 753, 2010.

Edwards, K. F., Klausmeier, C. A. and Litchman, E.: A Three-Way Trade-Off Maintains Functional Diversity under Variable Resource Supply. Am. Nat., 182(6), 786-800, doi:10.1086/673532, 2013.

Fang, Y., Koba, K., Makabe, A., Zhu, F., Fan, S., Liu, X. and Yoh, M.: Low ${ }^{1} 8 \mathrm{O}$ Values of Nitrate Produced from Nitrification in Temperate Forest Soils. Environ. Sci. Technol., 46(16), 8723-8730, doi:10.1021/es300510r, 2012.

Groffman, P. M.: Terrestrial denitrification: challenges and opportunities. Ecological Processes, 1(1), 1-11, 2012.

Jin, Q. and Bethke, C. M.: The thermodynamics and kinetics of microbial metabolism. American Journal of Science, 307(4), 643-677, doi:10.2475/04.2007.01, 2007.

Jones, C. M., Spor, A., Brennan, F. P., Breuil, M.-C., Bru, D., Lemanceau, P., Griffiths, B., Hallin, S. and Philippot, L.: Recently identified microbial guild mediates soil N2O sink capacity. Nature Climate Change, doi:10.1038/nclimate2301, 2014.

Kartal, B., Geerts, W. and Jetten, M. S.: 4 Cultivation, Detection, and Ecophysiology of Anaerobic Ammonium-Oxidizing Bacteria. Meth. Enzymol., 486 (Part A), 89-108, doi:10.1016/S0076-6879(11)86004-0, 2011.

Kendall, C., Elliott, E. M. and Wankel, S. D.: Tracing anthropogenic inputs of nitrogen to ecosystems. Stable isotopes in ecology, 2007.

LaRowe, D. E. and Van Cappellen, P.: Degradation of natural organic matter: A thermodynamic analysis. Geochimica et Cosmochimica Acta, 75(8), 2030-2042, doi:10.1016/j.gca.2011.01.020, 2011.

LaRowe, D. E., Dale, A. W., Amend, J. P. and Van Cappellen, P.: Thermodynamic limitations on microbially catalyzed reaction rates. Geochimica et Cosmochimica Acta, 90, 96-109, doi:10.1016/j.gca.2012.05.011, 2012.

Le Roux, X., Bouskill, N. J., Niboyet, A., Barthes, L., Dijkstra, P., Field, C. B., Hungate, B. A., Lerondelle, C., Pommier, T.,

Tang, J., Terada, A., Tourna, M. and Poly, F.: Predicting the Responses of Soil Nitrite-Oxidizers to Multi-Factorial Global Change: A Trait-Based Approach. Front. Microbiol., 7, doi:10.3389/fmicb.2016.00628, 2016. 
Litchman, E., Edwards, K. F. and Klausmeier, C. A.: Microbial resource utilization traits and trade-offs: implications for community structure, functioning, and biogeochemical impacts at present and in the future. Front. Microbiol., 6(e32003), 65, doi:10.3389/fmicb.2015.00254, 2015.

Molenaar, D., van Berlo, R., de Ridder, D. and Teusink, B.: Shifts in growth strategies reflect tradeoffs in cellular economics.

5 Mol Syst Biol, 5, doi:10.1038/msb.2009.82, 2009.

Rosso, L., Lobry, J. R., Bajard, S. and Flandrois, J. P.: Convenient Model To Describe the Combined Effects of Temperature and $\mathrm{pH}$ on Microbial Growth. Applied and Environmental Microbiology, 61(2), 610-616, 1995.

Sanford, R. A., Wagner, D. D., Wu, Q., Chee-Sanford, J. C., Thomas, S. H., Cruz-Garcia, C., Rodriguez, G., MassolDeya, A., Krishnani, K. K., Ritalahti, K. M., Nissen, S., Konstantinidis, K. T. and Loffler, F. E.: Unexpected nondenitri-

10 fier nitrous oxide reductase gene diversity and abundance in soils. Proc. Natl. Acad. Sci. U.S.A., 109(48), 19709-19714, doi:10.1073/pnas.1211238109, 2012.

Tang, J. and Riley, W. J.: Weaker soil carbon-climate feedbacks resulting from microbial and abiotic interactions. Nature Climate Change, doi:10.1038/nclimate2438, 2014.

Tilman, D.: Resource competition between plankton algae: an experimental and theoretical approach. Ecology, 338-348, 151977.

Tilman, D.: Further thoughts on competition for essential resources. Theoretical Population Biology, 32(3), 442-446, 1987.

Wallenstein, M. D., Myrold, D. D., Firestone, M. and Voytek, M.: Environmental controls on denitrifying communities and denitrification rates: insights from molecular methods. Ecol Appl, 16(6), 2143-2152, 2006.

Wexler, S. K., Goodale, C. L., McGuire, K. J., Bailey, S. W. and Groffman, P. M.: Isotopic signals of summer denitrification in 20 a northern hardwood forested catchment. Proc. Natl. Acad. Sci. U.S.A., 111(46), 16413-16418, doi:10.1073/pnas.1404321111, 2014.

\section{Supplemental Tables and Figures}




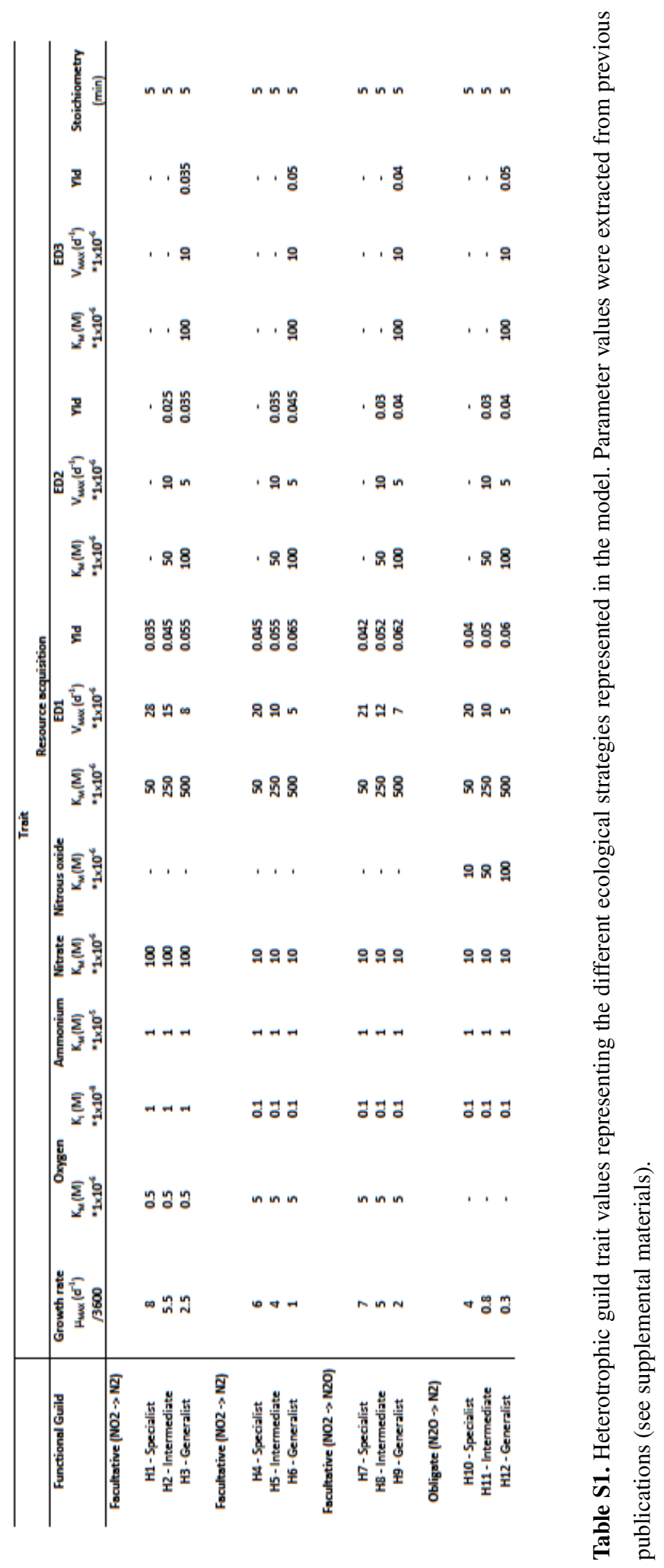




\begin{tabular}{|c|c|c|c|c|c|c|c|c|c|c|c|c|c|}
\hline \multirow{3}{*}{ Functional Guild } & \multicolumn{10}{|c|}{$\begin{array}{c}\text { Trait } \\
\text { Resource acquisition }\end{array}$} & \multirow{3}{*}{$\begin{array}{l}\text { Stoichiometry } \\
\text { CN }\end{array}$} & \multirow{3}{*}{$\begin{array}{l}\text { Yld } \\
/ \mathrm{CN}\end{array}$} & \multirow{3}{*}{ References } \\
\hline & \multirow{2}{*}{$\begin{array}{c}\text { Growth rate } \\
\mu_{\max }\left(d^{-1}\right) \\
/ 3600 \\
\end{array}$} & \multicolumn{3}{|c|}{ Ammonium/ Nitrite } & \multicolumn{3}{|c|}{ Nitrite } & \multirow{2}{*}{$\begin{array}{c}\text { Carbon Dioxide } \\
\mathrm{K}_{\mathrm{M}}(\mathrm{M}) \\
{ }^{*} 1 \times 10^{-6}\end{array}$} & \multicolumn{2}{|c|}{ Oxygen } & & & \\
\hline & & $\begin{array}{l}K_{M}(M) \\
* 1 \times 10^{-6}\end{array}$ & $\begin{array}{l}\mathrm{V}_{\max }\left(\mathrm{d}^{-1}\right) \\
{ }^{*} 1 \times 10^{-6}\end{array}$ & $\begin{array}{l}\mathrm{K}_{\mathrm{i}}(\mathrm{M}) \\
{ }^{*} 1 \times 10^{-6}\end{array}$ & $\begin{array}{l}K_{M}(M) \\
\cdot 1 \times 10^{-6}\end{array}$ & $\begin{array}{l}v_{\max }\left(d^{-1}\right) \\
{ }^{*} 1 \times 10^{-6}\end{array}$ & $\begin{array}{l}K_{f}(M) \\
\cdot 1 \times 10^{-6}\end{array}$ & & $\begin{array}{l}\mathrm{K}_{\mathrm{M}}(\mathrm{M}) \\
{ }^{*} 1 \times 10^{-6}\end{array}$ & $\begin{array}{l}\mathrm{K}_{\mathrm{f}}(\mathrm{M}) \\
*_{1 \times 10^{-7}}\end{array}$ & & & \\
\hline \multicolumn{14}{|l|}{ Ammonia-oxidation } \\
\hline AOB_1 & 0.9 & 200 & 10 & - & - & - & - & 1 & 3 & - & 6.6 & 0.04 & \\
\hline AOB_2 & 0.8 & 100 & 7 & - & - & - & - & 1 & 3 & - & 6.6 & 0.045 & See Bouskill et al., \\
\hline AOB_3 & 0.3 & 40 & 2 & - & - & - & - & 1 & 3 & - & 6.6 & 0.05 & 2012 for list of \\
\hline AOA_1 & 0.25 & 0.05 & 1.7 & 100 & - & - & - & 1 & 3 & - & 6.6 & 0.06 & \\
\hline \multicolumn{14}{|l|}{ Nitrite-oxidation } \\
\hline NOB_1 & 0.7 & 100 & - & - & 349 & 6 & - & 1 & 8 & & 6.6 & 0.04 & \\
\hline NOB_2 & 0.5 & 100 & - & - & 1035 & 8 & - & 1 & 10 & & 6.6 & 0.04 & Le Roux et al., 2016 \\
\hline $\mathrm{NOB}_{-}^{-} 3$ & 0.3 & 100 & - & - & 19 & 2 & - & 1 & 6 & & 6.6 & 0.05 & \\
\hline \multirow{2}{*}{\multicolumn{14}{|c|}{$\begin{array}{c}\text { Anaerobic ammonia } \\
\text { oxidation }\end{array}$}} \\
\hline & & & & & & & & & & & & & \\
\hline Amx_1 & 0.008 & 20 & 4 & - & 80 & 4 & 200 & 1 & - & 1 & 6.6 & 0.01 & \\
\hline Amx_2 & 0.004 & 0.5 & 1 & - & 0.5 & 1 & 50 & 1 & - & 1 & 6.6 & 0.01 & Kartel et al., 2012 \\
\hline
\end{tabular}

Table S2. Trait values used to initialize the different autotrophic functional guilds. Guilds represented include three groups of ammoniaoxidizing bacteria, three groups of nitrite-oxidizing bacteria, one group of ammonia-oxidizing archaea, and the groups of anaerobic ammonia oxidizers (anammox). Not all traits are represented in each functional guild

\begin{tabular}{c|ccc}
\hline & \multicolumn{3}{|c}{ Electron acceptor } \\
Electron Donor & Oxygen & Nitrate & Nitrous oxide \\
\hline ED1 & 18.3 & 16.9 & 25.6 \\
ED2 & 19.6 & 19.9 & 26.8 \\
ED3 & 18.5 & 16.4 & 26.5
\end{tabular}

Table S3. Activity coefficients (given as $\log \left(\mathrm{K}_{e q}\right)$ ) associated with the $\mathrm{ED}_{1,2,3}$ relative to different electron acceptors. 


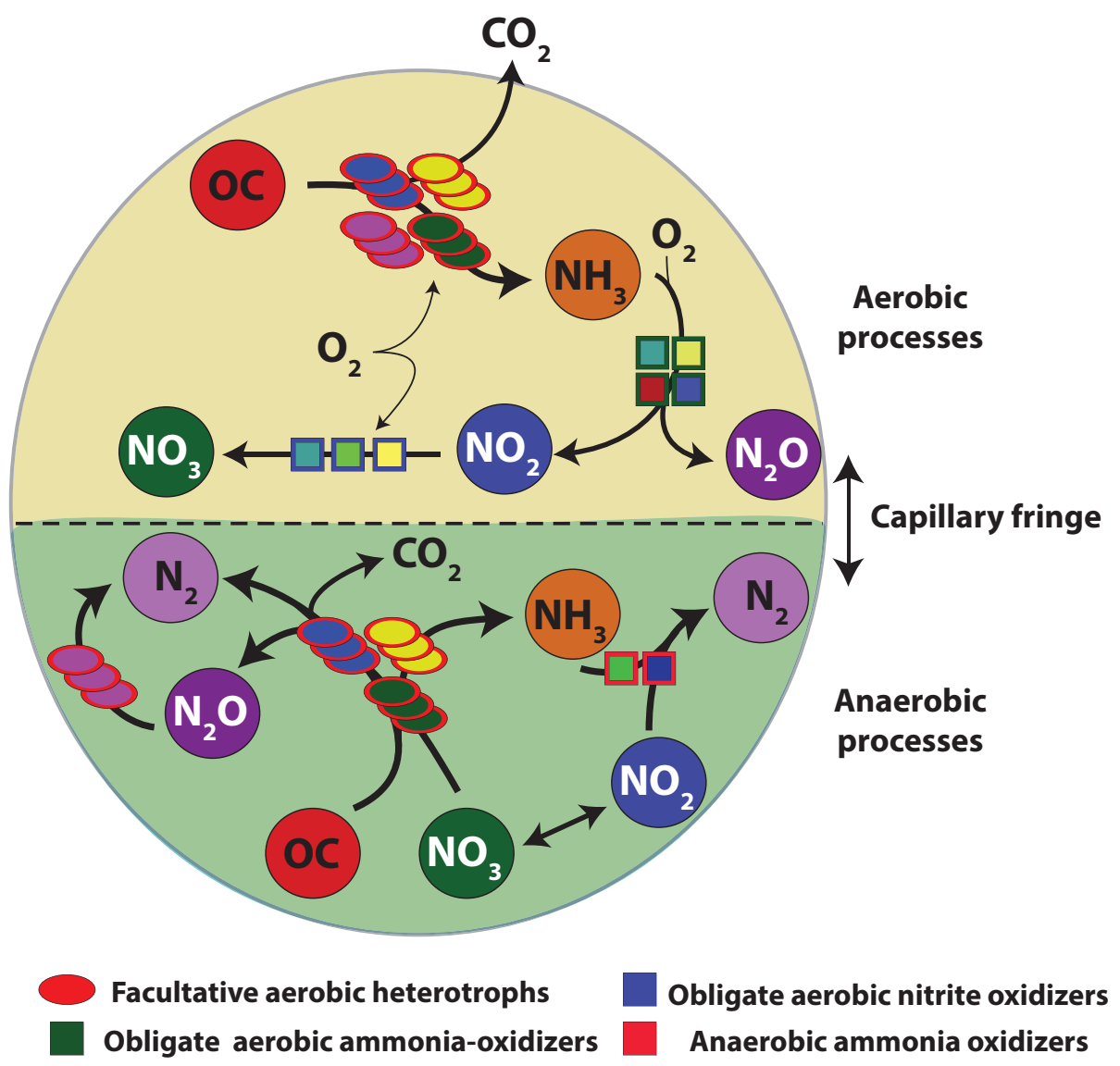

Figure S1. Model representation of interactions between autotrophic and heterotrophic guilds at the capillary fringe. 

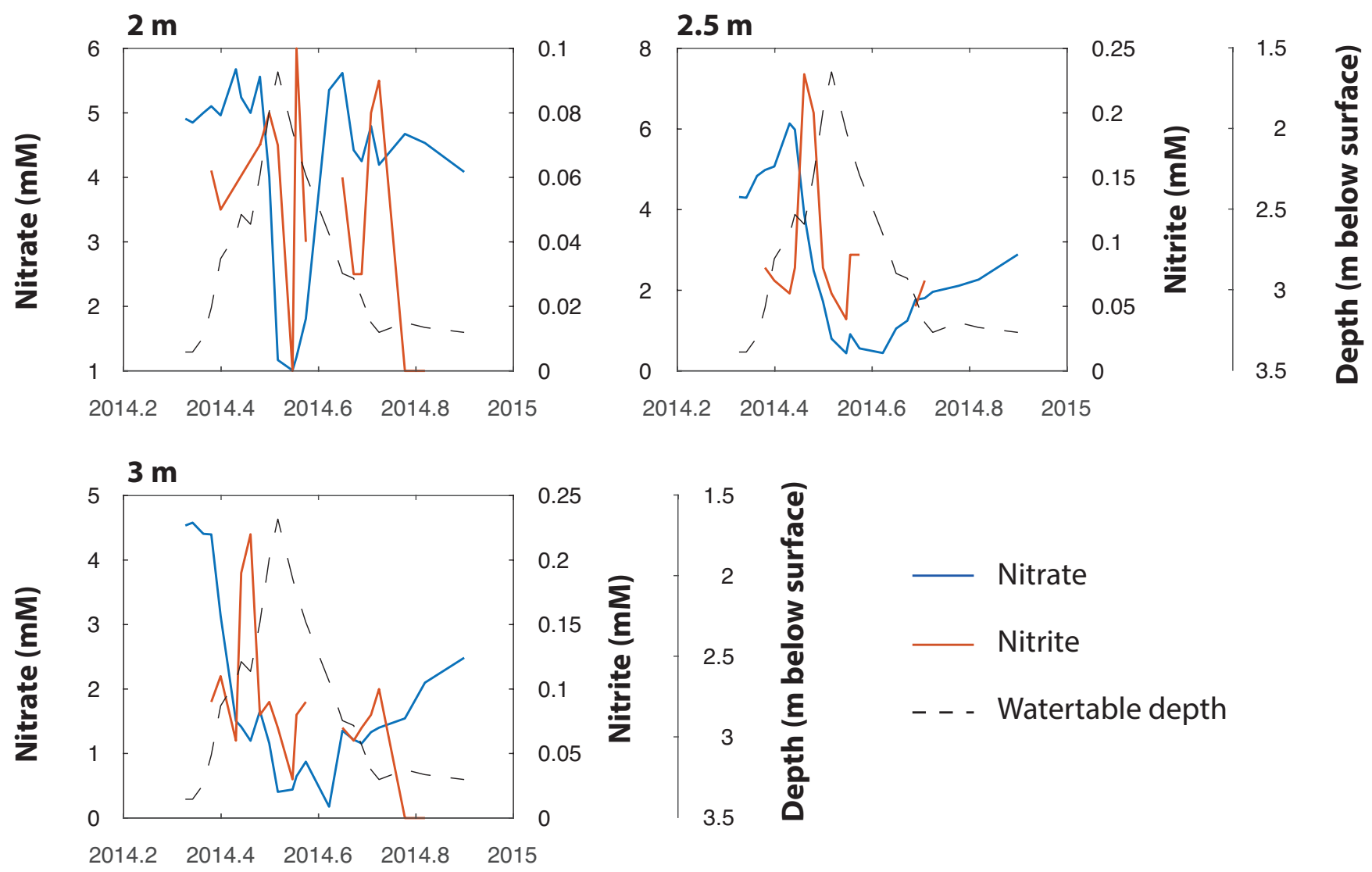

\section{Time (yr/mth)}

Figure S2. Nitrate (right axis) and nitrite (left axis) measurements at 2.0, 2.5 and $3.0 \mathrm{~m}$ bgs in TT-03 during 2014. The plots show coincidental and temporally lagged production of nitrite as nitrate declines, followed by apparent loss of nitrite. The water table depth is represented by the black dotted line. 


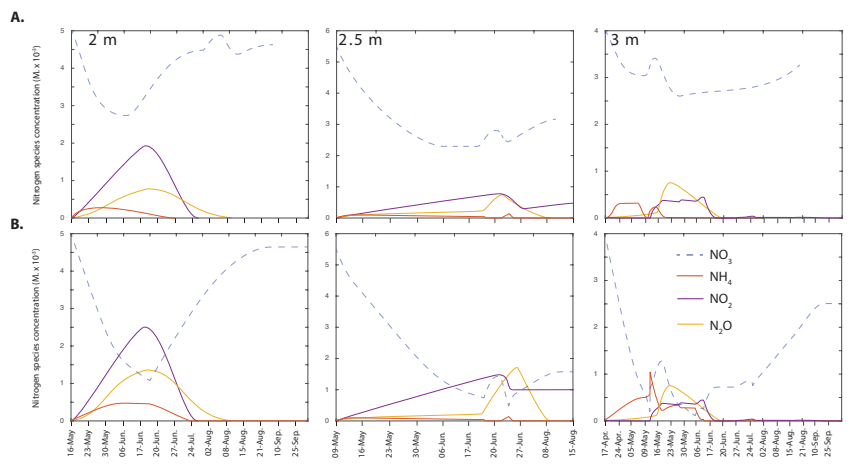

Figure S3. Geochemical output $\left(\mathrm{NH}_{4}{ }^{+}, \mathrm{NO}_{2}{ }^{-}, \mathrm{NO}_{3}{ }^{-}, \mathrm{N}_{2} \mathrm{O}\right)$ from the microbial model at discrete depths and organic matter concentrations. A. Model response under OM concentrations typical of the aquifer (corresponding microbiological community response is given in Fig. 3 of the main text). B. Geochemical response under OM concentrations an order of magnitude higher than in A. Under these conditions microbial activity can account for all of the $\mathrm{NO}_{3}{ }^{-}$through denitrification.
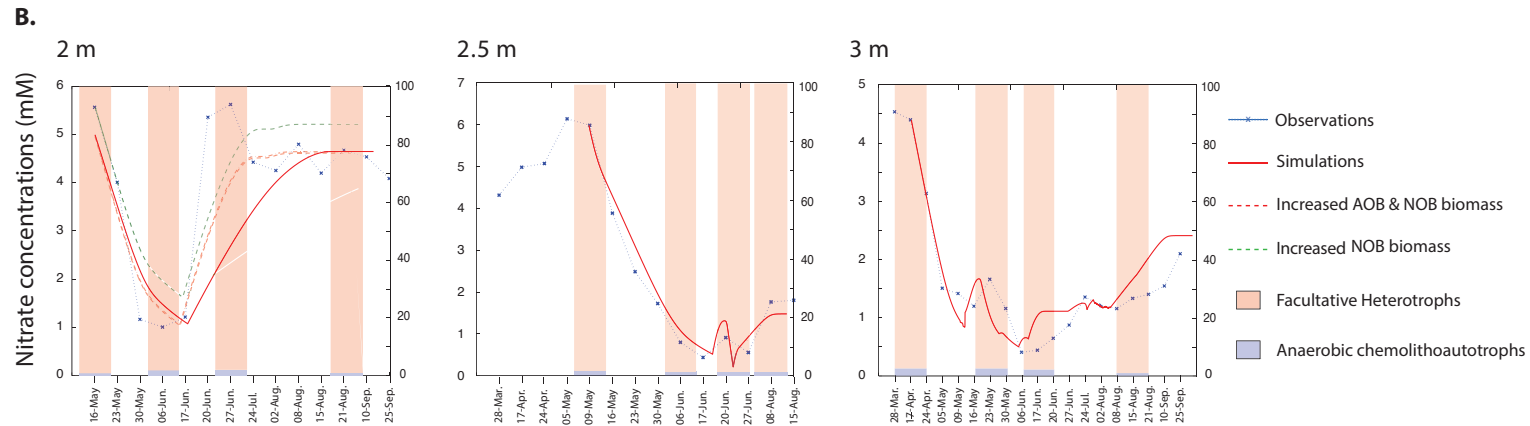

Figure S4. Microbiological community response under high OM concentrations (an order of magnitude higher than that in the main text). The corresponding geochemical response is given above (Fig. S3). 

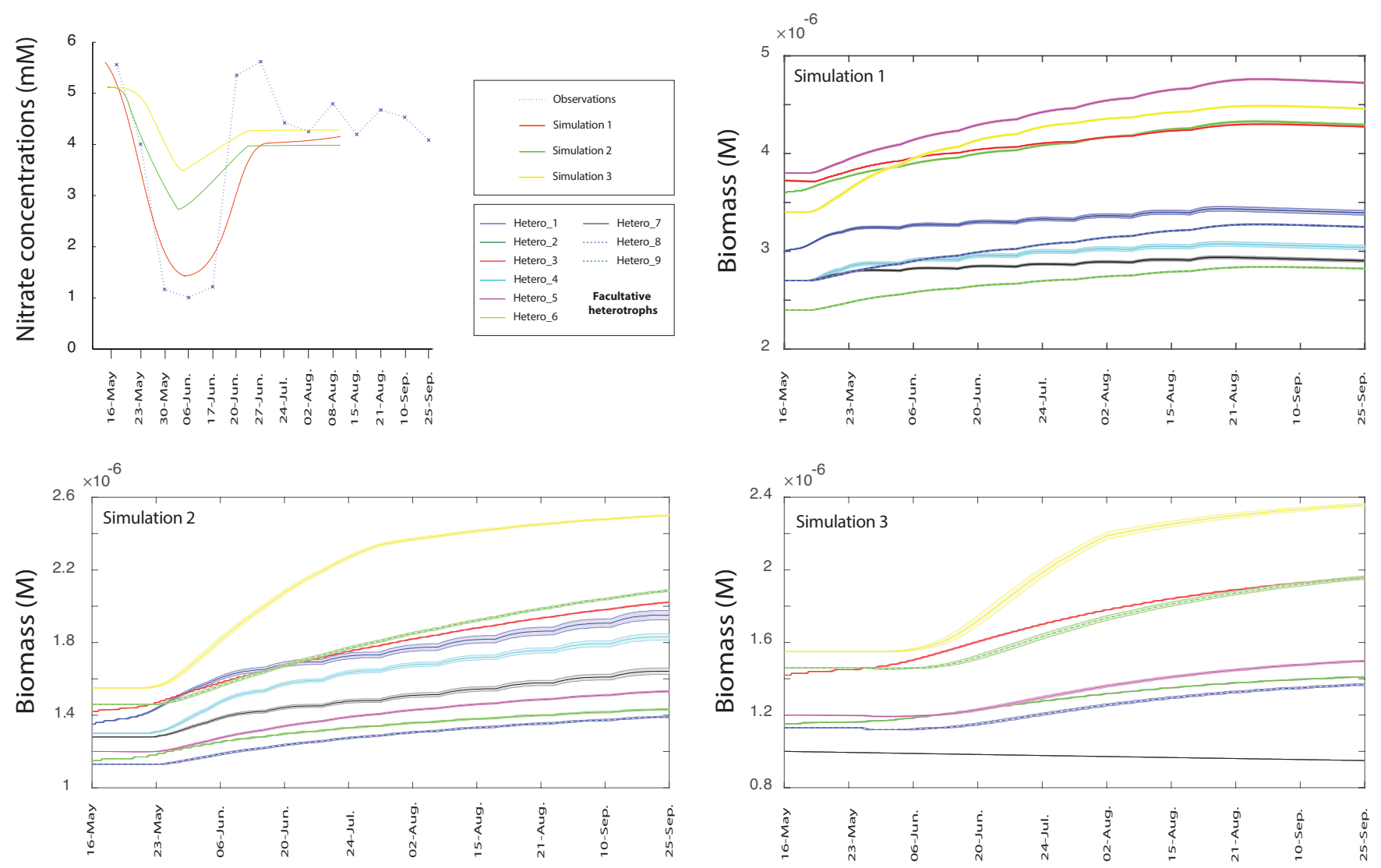

Figure S5. Heterotrophic community trajectory under different electron donor ratios. The relative ratios of $\mathrm{ED}_{1-3}$ was manipulated while maintaining the same concentration $(\sim 30 \mu \mathrm{M})$ pulsed at regular intervals. Simulation 1 represents the default simulation with $\mathrm{ED}_{1,2,3}$ ratio of 50:25:25, simulation 2 increases the concentration of $\mathrm{ED}_{3}$ to give a final ratio of 25:25:50, while the final simulation gives a splits the total $\mathrm{OM}$ concentration between $\mathrm{ED}_{2}$ and $\mathrm{ED}_{3}$ equally. 
$C: N=3$
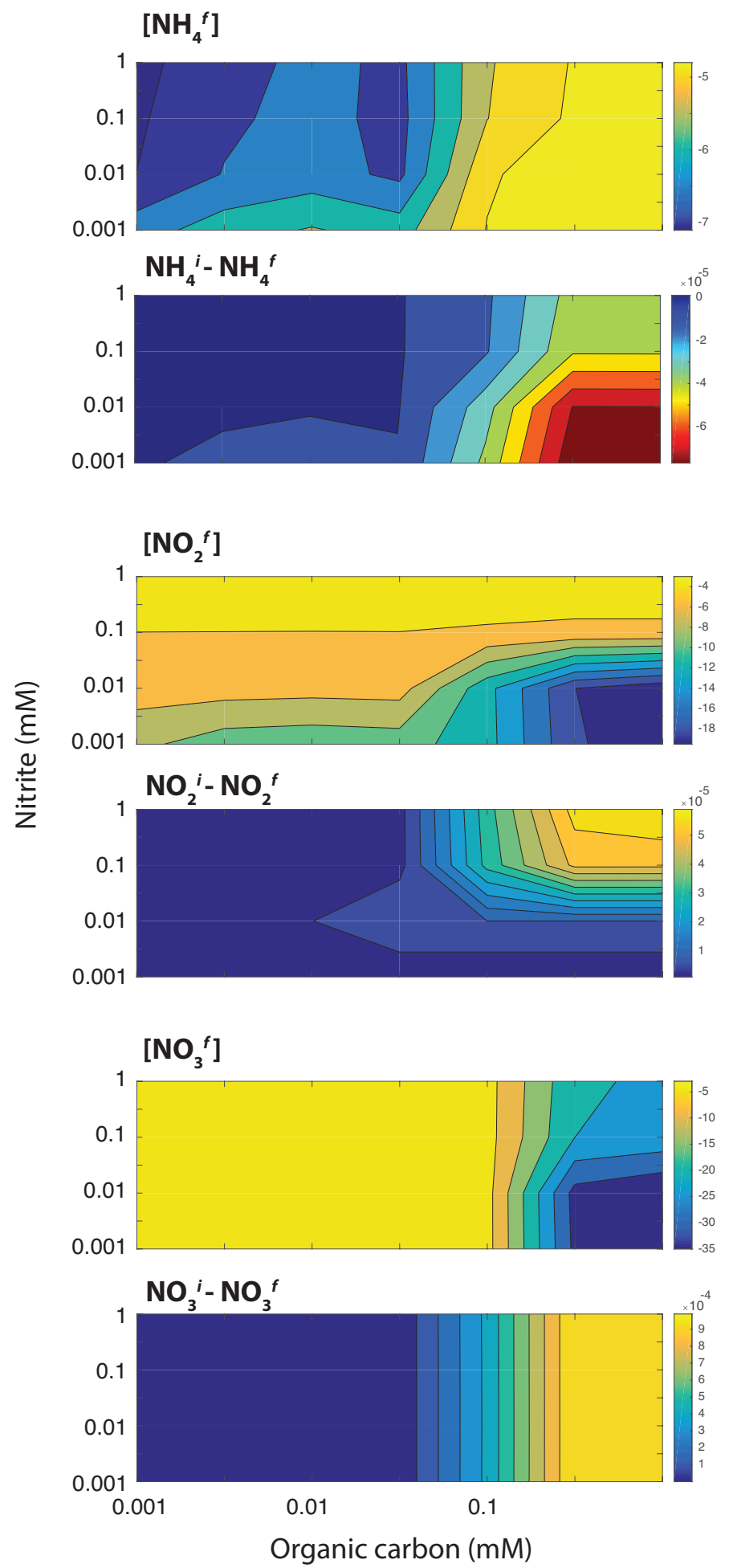

$C: N=15$

\section{$\left[\mathrm{NH}_{4}{ }^{f}\right]$}
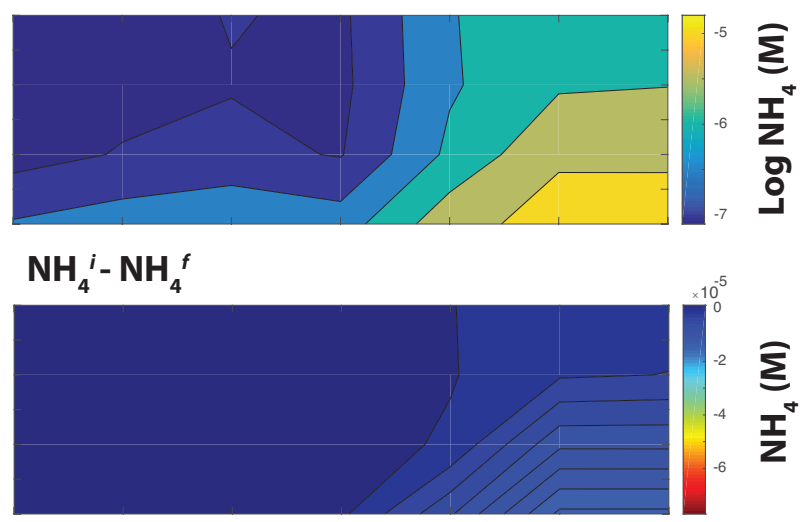

$\left[\mathrm{NO}_{2}{ }^{f}\right]$
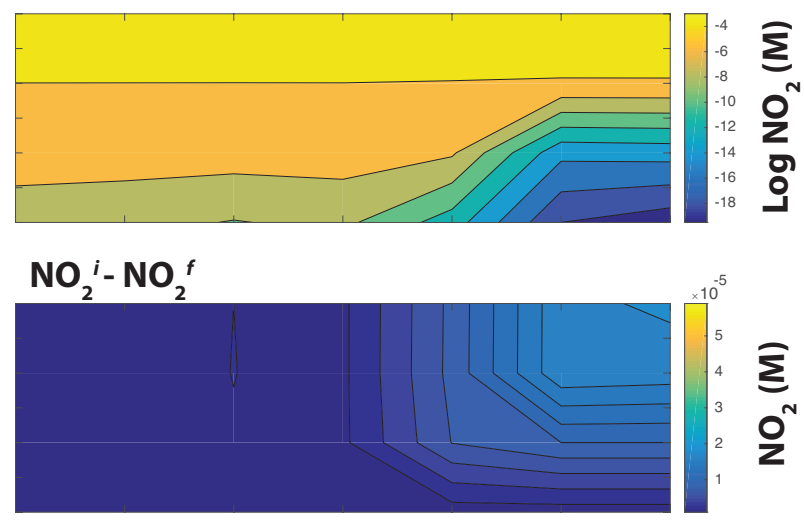

$\left[\mathrm{NO}_{3}{ }^{f}\right]$
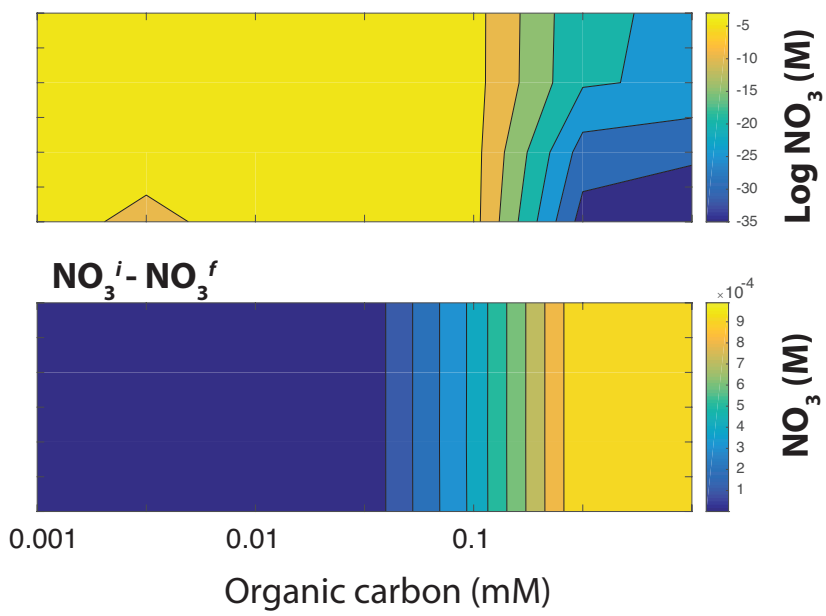

Figure S6. $\mathrm{NH}_{4}{ }^{+}, \mathrm{NO}_{2}{ }^{-}$, and $\mathrm{NO}_{3}{ }^{-}$distribution across gradients in $\mathrm{N5}_{2}{ }^{-}$and organic matter concentration at $\mathrm{C}: \mathrm{N}$ ratios of 3 and 15 . Panels show the final concentration of each species at the end of the simulation, and the difference between starting and finishing concentrations. The color differences in the $\mathrm{NH}_{4}{ }^{+}$represents its accumulation. 
Low groundwater height

(Fall to early spring)

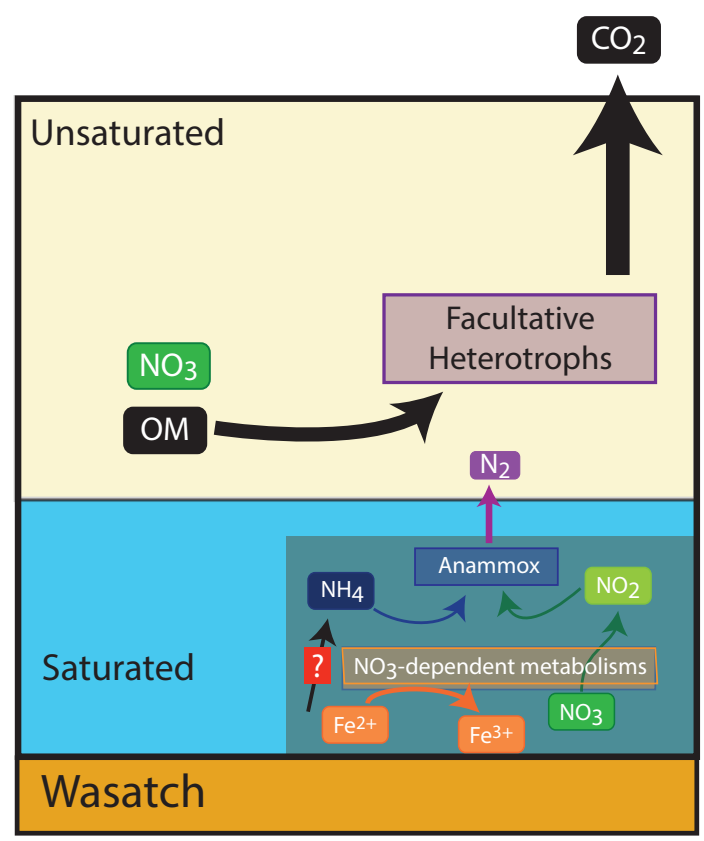

During groundwater rise

(Spring to Fall)

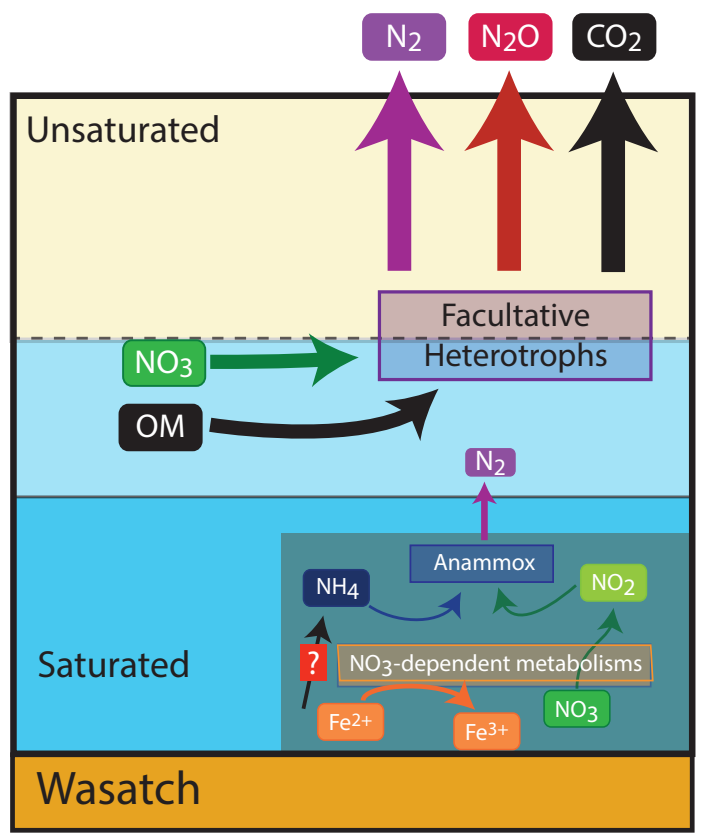

Figure S7. Conceptual nitrogen cycle within the Rifle aquifer on the basis of the measurements made in the present study, and recent molecular based studies. 